\title{
International Experience in Anti-Theft of Catalytic Converters Installed in Cars
}

Recently, there has been an increase in the number of property crimes in the world, including theft of external car parts.

The number of thefts of catalytic converters installed in cars of various brands has sharply increased due to a significant increase in the value of precious metals such as platinum, palladium and rhodium present in small amount in the catalytic convertors.

The purpose of this article is to consider this problem faced by law enforcement and legislative bodies in many countries and to propose certain ways for its solution.

The article provides an overview of the situation with thefts of catalytic converters in the countries of the European Union, the United States and Israel. Detailed reasons for the occurrence of this problem are provided, as well as measures to protect cars from the theft are suggested.

Possible legislative and investigative-forensic actions to prevent this type of crime are considered:

- law enforcement agencies investigating this type of crime should clearly understand that we are not talking about isolated, unrelated cases, but about well-planned actions of criminal groups.

- increase in control over purchase and sale of metal carried out without accounting and corresponding documentation and amendments to the administrative procedural code also require strengthening.

- applying a special forensic marking on parts, including on a catalytic converter, will allow to track its location and provide full information to law enforcement agencies from which vehicle it was stolen in the event of its theft.

- inspection and examination by forensic expert of vehicles and other physical evidence left by criminals at crime scenes such as fingerprints and DNA profiles will help to significantly increase the detection rate of this type of crime.

Keywords: catalytic converter, palladium, car parts theft, forensic marking.

Introductoin. The world is struggling through the COVID-19 pandemic: unprecedented in modern history in terms of the number of the ill and socio-economic consequences. The pandemic significantly influences the economic development of countries and lifestyle of population.

Due to the unstable economic situation of countries, the quantity of property crimes, including car thefts as well as external car parts, has increased.

Thus, according to the statistics of the National Insurance Crime Bureau (NICB), the number of car thefts in 2020 grew by $9.2 \%$ compared with 2019.

\section{R. Pertsev}

INTERNATIONAL EXPERIENCE IN ANTI-THEFT OF CATALYTIC CONVERTERS INSTALLED IN CARS.

Recently, there has been increase in the number of property crimes in the world, including theft of external car parts.

The number of thefts of catalytic converters installed in cars of various brands has sharply increased due to a significant increase in the value of precious metals such as platinum, palladium and rhodium. The reason for a sharp increase in the number of crimes of this particular car part is small amounts of the mentioned precious metals in the catalytic convertors.

The purpose of this article is to consider this problem faced by law enforcement and legislative bodies in many countries and to propose certain ways for its solution.

The article provides an overview of the situation with thefts of catalytic converters in the countries of the European Union, the United States and Israel. Detailed reasons for the occurrence of this problem are provided, as well as measures to protect a car from the theft are suggested.

Possible legislative and investigative-forensic actions to prevent this type of crime are considered:

- law enforcement agencies investigating this type of crime should clearly understand that we are not talking about isolated, 


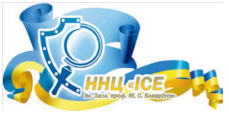

unrelated cases, but about wellplanned actions of criminal groups. increase in control over purchase and sale of metal carried out without accounting and corresponding documentation and amendments to the administrative procedural code also require strengthening.

applying a special forensic marking on parts, including on catalytic converter, will allow to track its location and provide full information to law enforcemen agencies from which vehicle it was stolen in the event of its theft.

inspection and examination by a forensic expert of vehicles and other physical evidence left by criminals at crime scenes for criminals' fingerprints and DNA profiles will help to significantly increase the detection rate of this type of crime.

Keywords: catalytic converter, palladium, car parts theft, forensic marking.

\section{Р. В. Перцев}

МЕЖДУНАРОДНЫЙ ОПЫТ ПРОТИВОДЕЙСТВИЯ КРАЖАМ КАТАЛИТИЧЕСКИХ НЕЙТРАЛИЗАТОРОВ С АВТОМОБИЛЕЙ

В последнее время в мире наблюдается увеличение количества имущественных преступлений, в том числе краж внешних деталей автомобиля.

C резким повышением стоимости благородных металлов, таких как платина, палладий и родий, увеличилось и количество краж каталитических нейтрализаторов, установленных в автомобилях различных марок. Причиной стремительного увеличения числа краж именно этой детали автомобиля стало содержание в них небольшого количества вышеуказанных драгоценных металлов.

Целью этой статьи является рассмотрение данной проблемы, с которой столкнулись правоохранительные

законодательные органы многих стран, и предложение некоторых путей ее решения.

В статье приведен обзор ситуации с кражами каталитических нейтрализаторов в странах Европейского союза, США, а также Израиля.

Рассмотрены подробные причины возникновения данной проблемы, рекомендованы меры по защите автомобиля от кражи.

Предложены возможные законодательные и следственнокриминалистические действия
International Experience in Anti-Theft of Catalytic

Converters Installed in Cars

Furthermore, based on the data provided by the National Insurance Bureau, throughout the whole territory of the United States of America (hereinafter referred to as the USA), the number of thefts of catalytic converters installed in cars has surged. According to the USA police data, the number of catalytic converters thefts is expected to increase by another $30 \%{ }^{1}$ in $2021-2022$.

The reasons for such a sharp increase in the number of thefts and methods of preventing this kind of crime require a thorough study.

Analysis of Essential Researches and Publications. The number of thefts of external car parts has been growing from year to year, but according to the data of some researches, these figures can be understated in view of the fact that people do not address the police in such types of crimes ${ }^{2}$. A sharp increase in the number of thefts of catalytic converters installed in cars is associated with its structure and manufacturing materials which consist of noble metals (palladium, iridium, platinum) ${ }^{3}$. Only according to official data from the United Kingdom police, the quantity of catalytic converter thefts in 2020 multiplied six times in comparison to previous years ${ }^{4}$.

The Article Purpose. The purpose of this article is to identify the problem that has arisen over the last few years in the countries of the European Union, the USA and Israel, associated with the theft of external car parts, in particular catalytic converters; to consider technical, forensic and legal methods for resolving this problem; to share practical experience accumulated by police units of various countries who have been faced with the great number of thefts of catalytic converters.

Main Content Presentation. Currently, the world is fighting the pandemic which consequences affect not only the physical condition of society but also socio-economy. Police divisions and insurance companies of many countries faced the doubled number of thefts of catalytic converters installed in cars in recent years (in some countries they are stolen in tens of thousands per year).

To understand why there has been such a dramatic increase in the number of catalytic converters theft, first of all let's consider its device. The catalytic converters (common name is the catalyst) in the structure of the exhaust system is designed to reduce the emission of harmful substances into the atmosphere with end gases due to their conversion to harmless components. The catalyst is used both in gasoline and diesel engines. The basis of the catalyst consist of ceramic or metallic cells. Depending on the model, a microlayer from platinum, palladium, rhodium or iridium is applied on the walls of the cells. These metals possess high chemical activity. As for spraying, a part of the exhaust reacts with it. Some elements formed during the combustion of fuel bind, thereby reducing emissions of harmful substances.

The value of these noble metals comprising the catalysts has recently grown drastically. Thus, the palladium precious metal by January 2020 was traded at about $\$ 2,500$ per troy ounce an increase of $350 \%$ from the beginning of 2016. Another precious metal: rhodium traded at a mark of $\$ 9,400$ per ounce from the beginning of 2016 its value has increased by $1303 \%$. Palladium, rhodium are used mainly for catalysts production. The demand for rhodium also exceeds its supply in the global market: that affects the rapid growth of its value ${ }^{5}$. On average, the standard catalyst consists

\footnotetext{
Pandemic Brings Spike In Theft Of Cars And Catalytic Converters, Forbes Advisor 2021. URL: https://www.forbes.com/advisor/car-insurance/stolen-cars-catalytic-converters

Sallybanks, J., \& Thomas, N. (2000). Thefts of External Vehicle Parts: An Emerging Problem. Crime Prevention and Community Safety, 2(3), 17-22. DOI:10.1057/palgrave.cpcs.8140062

Milton, B. E. (1998). Control Technologies in Spark-Ignition Engines. Handbook of Air Pollution From Internal Combustion Engines, 236-239. DOI:10.1016/b978-012639855-7/50047-8

4 Catalytic converter thefts: Surge in cases reported to Met Police, BBC News 2021. URL:https:// www.bbc.com/news/uk-england-london-56502390

Взрывной рост цен на рынке палладия и родия, 2020 г. URL: https://gold.ru/news/ vzryvnoj-rost-cen-na-rynke-palladiya-i-rodiya.html (date accessed: 26.03.2021)
} 
of these noble metals, the amount of the precious metal depends on the manufacturer and car model.

In recent years, metal theft has become a serious criminal phenomenon in the European Union member countries. Thieves also encroach on catalytic converters from parked cars, since they contain precious metals.

The European Union Police Service (EUROPOL) participated in the international investigation carried out by the French and Bulgaria police to eliminate the criminal network involved in the theft of catalytic converters in France. Europol supported a rapid exchange of intelligence information between police headquarters of countries conducting this investigation. According to the investigation, the total loss of this criminal network can be 650 thousand euros ${ }^{6}$.

According to the London police, about 100 catalysts are stolen monthly. Thus, based on statistics, the number of such crimes has grown by $455 \%$ comparing to the previous year?.

Referring to the information provided by the English police from the West Yorkshire county, the following brands of cars are frequently encroached on: Toyota Prius, Toyota Auris, Honda Jazz and Honda CR-V.

In addition, the police have issued certain recommendations for citizens to reduce the possibility of theft of catalytic converters installed in cars.

It is recommended to park a car in a locked garage. When it is impossible: in a well-lit and densely populated place; if the catalytic converter is bolted, you can ask to weld bolts in an automobile repair shop so that it will be harder to disassemble and steal; you can purchase the "catalyst lock": a cage that is fixed around the converter to complicate its removal and theft; installation of sensitive alarm in a car as well as catalysts ${ }^{8}$ marking.

According to data from open sources in Israel, the catalytic converter installed in a car has become one of the most stolen items in 2020. Only over the past few months, more than hundred catalysts were stolen mainly from Toyota and Subaru Impreza brand cars. Tens of gangs specializing in theft of catalytic converters operate in the country due to the high demand for precious metals and ease in committing a theft. Although the punishment stipulated for the dismantlement and theft of vehicle parts, according to the Israel's Penal Code, is quite severe and the subject to five years of imprisonment ${ }^{9}$, it does not stop criminals from making an "easy prey" profit.

A sharp increase in the number of thefts of catalysts has become a blow to the Israeli police. It also causes an economical damage to citizens estimated by tens of millions of shekels, since the replacement of only one stolen catalyst will cost a car owner from about $\$ 1,000$ to $\$ 2,000$ (depending on a car brand). For the investigation, a special group was created which recently managed to arrest several criminal gangs as well as to catch criminals with corpus delicti at a crime scene and withdraw some parts of stolen catalysts.

\footnotetext{
${ }^{6}$ Europol supports dismantling of gang specialised in the theft of catalytic converters. URL: https://www.europol.europa.eu/newsroom/news/europol-supports-dismantling-of-gangspecialised-in-theft-of-catalytic-converters (date accessed: 25.03.2021

Over 1,000 catalytic converters cut from cars in London every month, Evening Standard 2020. URL: https://www.standard.co.uk/news/crime/catalytic-converter-theft-london-a4359216. html (date accessed: 26.03.2021).

8 Catalytic Converter Theft Prevention Advice. URL: https://www.westyorkshire.police.uk/ advice/vehicle-crime/vehicle-crime/catalytic-converter-theft-prevention-advice (date accessed: 26.03.2021)

9 Уголовный кодекс Израиля 1977 года, статья № 413 Кража из транспортного средства или разборка транспортного средства (Поправка № 28) 1990 г. URL: https://www.nevo.co.il/ law_html/law01/073_002.htm\#Seif327
}

для предотвращения данного вида преступления:

- органам правопорядка, расследующим данный вид преступления, следует четко понимать что речь идет не о единичных не связанных между собой случаях а о спланированных действиях преступных групп;

- необходимо усиление контоля за скупкой и продажей металла, которые ведутся без учета и соответствующей документации, и внесение соответствующих изменений в административно-процессуальный кодекс;

- нанесение спциальной криминалистической маркировки на детали, в том числе и на каталитический нейтрализатор, позволит в случае кражи отследить его место нахождение и дать исчерпывающую информацию органам правопорядка, с какого именно транспортного средства он был украден;

- проверка и исследование экспертом-криминалистом автотранспортных средств и других вещественных доказательств, оставленных преступниками на местах преступлений, на наличие отпечатков пальцев и ДНК-профилей преступников поможет в значительной степени повысить раскрываемость данного вида преступления.

Ключевые слова: каталитический нейтрализатор, палладий, кража деталей автомобиля, криминалистическая маркировка.

\section{Р. В. Перцев}

МІЖНАРОДНИЙ ДОСВІД ПРОТИДІЇ КРАДІЖКАМ КАТАЛІТИЧНИХ НЕЙТРАЛІЗАТОРІВ 3 АВТОМОБІЛІВ

Останнім часом у світі простежується збільшення кількості майнових злочинів, зокрема крадіжок зовнішніх деталей автомобіля.

Iз різким підвищенням вартості благородних металів, як-от платина, паладій і родій, збільшилася иे кількість крадіжок каталітичних нейтралізаторів, установлених в автомобілях різноманітних марок. Причиною стрімкого збільшення числа крадіжок саме цієї деталі автомобіля став уміст у них незначної кількості вищезазначених дорогоцінних металів.

Метою цієї статті є розгляд даної проблеми, із якою зіткнулися правоохоронні й законодавчі органи багатьох країн, та пропонування деяких шляхів тї вирішення. 


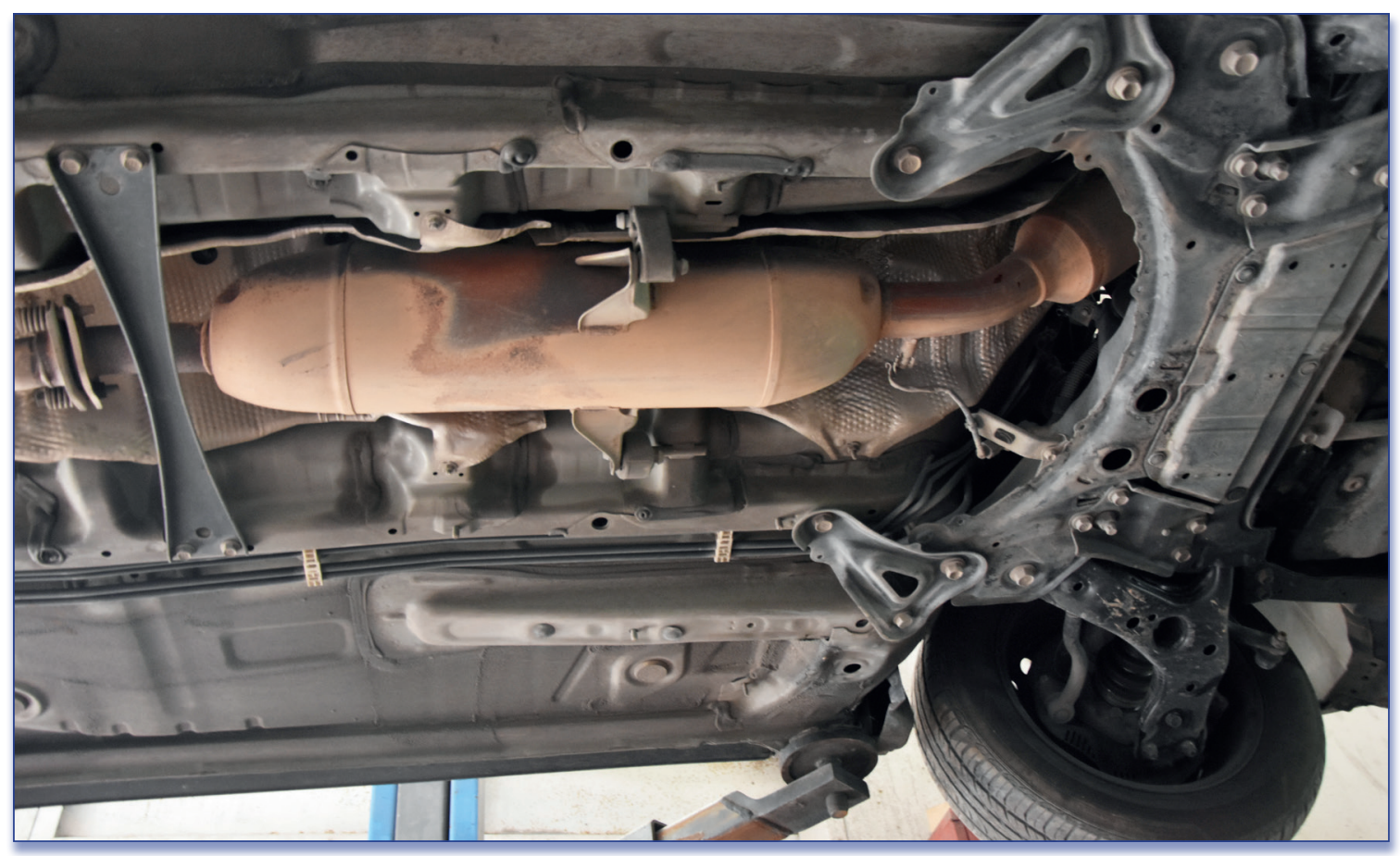

Fig. 1. The position of the catalytic converter in the Toyota Corolla car of 2010 (the catalyst is highlighted with a red circle).

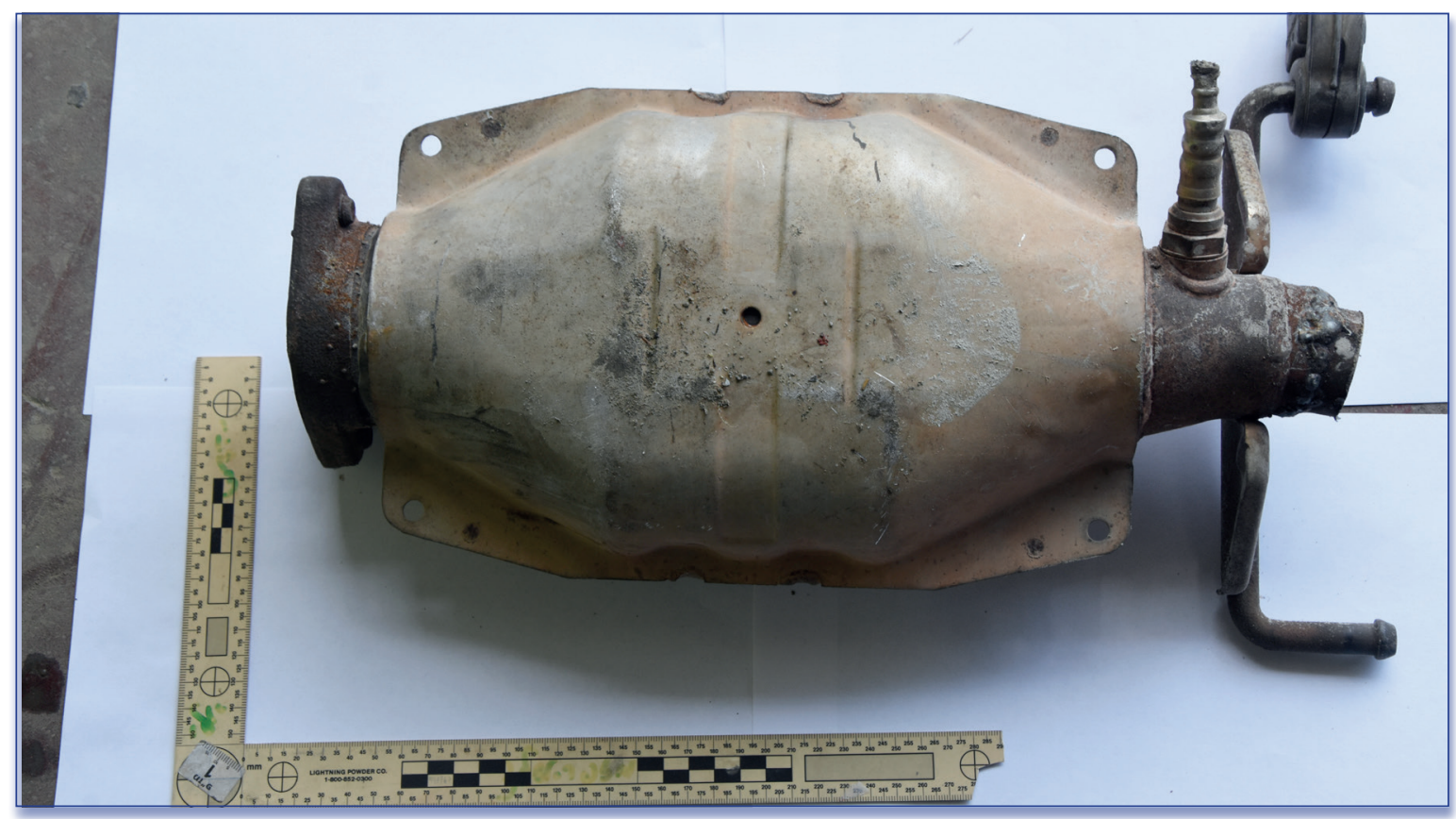

Fig. 2. A catalytic converter (there are different types and sizes of catalytic converters). 
These actions enabled to suspend the "wave" of catalytic converters theft, but such crimes cannot be completely eradicated ${ }^{10}$.

Let's discuss some reasons why criminals are aimed exactly on cars of certain brands, and how the process of catalytic converter theft happens.

Firstly, a car size. Criminals in the United States oftentimes steal catalysts installed in small trucks and off-road vehicles, as there is no need to use a lift while theft which in turn reduces the time of disassemble and direct theft of the catalyst.

Secondly, the position of the catalyst in a car. In some car brands, it is much more difficult to get to and disassemble the catalyst, as it is placed inside the engine compartment in contrast to (for example) the Ford, Subaru Impreza, Toyota Corolla brand cars, where the catalyst is placed under the car bottom (see fig. 1).

Thirdly, in hybrid vehicles, for example in Toyota Prius, there are two sources of energy: electrical, petrol or diesel. The catalytic converter is used less frequently for pollutants treatment. Metals are less likely subjected to corrosion, thereby their value is increasing and consequently they become more attractive for thieves.

The theft of catalytic converter directly takes place by lifting the parked car with a jack (jackscrew or hydraulic jack) and further twisting of the catalyst fasteners or cutting of the catalytic converter fastening system with a manual metal-working saw.

According to data from open sources obtained from surveillance cameras, it only takes a few minutes for criminals to steal a catalytic converter installed in a car.

You can see the example of such cut out catalyst in fig. 2.

Combating thefts of exterior car parts is highly difficult for a variety of reasons, one of which: accessibility and insecurity of such parts in cars. Furthermore, many external parts, including a catalytic converter, do not have an identification number, and it is impossible to trace the involvement of these parts to thefts in the event of their theft. Though some companies offer a simple, inexpensive and effective way of theft protection: you get from them an identification number built in a piece of tape for about 30 dollars. The tape is attached to the catalytic converter; the chemical is applied on it to engrave the number on parts. There is an app related to the central database that now can track the converter in your $\operatorname{car}^{11}$. There is also the so-called forensic marking of parts. Thus, details are assigned a unique code registered on an individual car which provides indisputable tracking of this part and enables to establish a link between a part and a specific $\mathrm{car}^{12}$.

Another problem for identifying stolen parts may be legal tracking of metals buying, there are-many metal purchasers pay in cash and do not request documents from sellers.

Strengthening the legislative control will allow to piece together chains of parts origin and complicate the ability to sell stolen parts and parts without corresponding documents.

Owners of motor vehicles subjected to thefts not always address the police with theft cases, and immediately head to an automobile repair shop for a car repair.

Therefore, these thefts remain not accountable in statistics, and the vehicle is not checked by an expert-criminalist. The possibility of disclosing

10 Белое золото: так воровство каталитических нейтрализаторов стало бедствием, Mako 2021. URL: https://www.mako.co.il/men-stories/Article-8e69c4614594771027.htm (date accessed: 27.03.2021)

11 Lorraine Explains: Catalytic converters stolen from under our cars, noses, Driving. URL: https:// driving.ca/column/lorraine/lorraine-explains-catalytic-converters-stolen-from-under-our-carsnoses (date accessed: 27.03.2021)

12 Turning The Tide On Catalytic Converter Theft, Police Life. URL: https://www.police-life. co.uk/products/turning-the-tide-on-catalytic-converter-theft (date accessed: 27.03.2021).

У статті наведений огляд ситуацій 3 крадіжками каталітичних нейтралізаторів у країнах Європейського союзу, США, а також Ізраїлю.

Розглянуті докладні причини виникнення даної проблеми, рекомендовані заходи щодо захисту автомобіля від крадіжки

Запропоновані можливі законодавчі та слідчо-криміналістичні дії для запобігання даного виду злочину:

органам правопорядку, які розслідують даний вид злочину, варто чітко розуміти, що йдеться не про поодинокі не пов'язані між собою випадки, а про сплановані дії злочинних груп;

- необхідне посилення контролю за скуповуванням і продажем металу, котрі здійснюються без обліку й відповідної документації, та внесення відповідних змін в адміністративно-процесуальний кодекс;

- нанесення спеціального криміналістичного маркування на деталі, зокрема й на каталітичний нейтралізатор, дозволить в разі крадіжки відстежити його місце перебування й надати вичерпну інформацію органам правопорядку, із якого саме транспортного засобу він був украдений;

перевірка ѝ дослідження кспертом-криміналістом автотранспортних засобів та інших речових доказів, залишених зловмисниками на місцях злочинів, на наявність відбитків пальців і ДНК-профілів злочинців допоможе значною мірою підвищити розкриваність даного виду злочину.

Ключові слова: каталітичний нейтралізатор, паладій, крадіжка деталей автомобіля, криміналістичне маркування.

R. Pertsev

\section{EXPÉRIENCE}

INTERNATIONALE DE LA

LUTTE CONTRE LE VOL

DE NEUTRALISATEURS

CATALYTIQUES DEPUIS DES

VOITURES

Récemment, il y a eu une augmentation du nombre de crimes contre les biens dans le monde y compris le vol de pièces détachées automobiles.

Avec la forte hausse du coût des métaux précieux comme le platine, le palladium et le rhodium, le nombre de vols de pots catalytiques installés dans des voitures de différentes marques a également augmenté. La raison de 
International Experience in Anti-Theft of Catalytic

Converters Installed in Cars

l'augmentation rapide du nombre de vols de cette partie de la voiture était leur contenu.

Le but de cet article est d'examiner le problème auquel sont confrontés les forces de l'ordre et les législatures dans de nombreux pays et de proposer des solutions.

L'article donne un aperçu de la situation des vols de pots catalytiques dans l'Union européenne, aux États-Unis et en Israël.

Les causes détaillées de ce problème sont prises en compte, des mesures de protection de la voiture contre le vol sont recommandées.

Proposition d'actions législatives et criminalistiques possibles pour prévenir ce type de délit:

- les services répressifs qui enquêtent sur ce type de crime doivent clairement comprendre qu'il ne s'agit pas de cas isolés et non liés, mais d'actions planifiées de groupes criminels;

- il est nécessaire de renforcer le contrôle sur l'achat et la vente de métal qui sont effectués sans tenir compte de la documentation pertinente et d'apporter les modifications appropriées au code de procédure administrative;

- l'application de marquages criminalistiques spéciaux sur les pièces y compris le convertisseur catalytique, permettra en cas de vol de suivre sa localisation et de fournir des informations complètes aux forces de l'ordre à partir de quel véhicule il a été volé;

- l'inspection et l'examen par un expert judiciaire des véhicules et autres preuves physiques laissées par des criminels sur les scènes de crime pour détecter la présence d'empreintes digitales et de profils DNA de criminels augmenteront considérablement la détection de ce type de crime.

Mots-clés: convertisseur catalytique, palladium, vol de pièces automobiles, marquage criminalistique.

Pertsev R.

INTERNATIONALE

ERFAHRUNG DER

GEGENWIRKUNG DER

DIEBSTÄHLE VON

FAHRZEUGKATALYSATOREN

AUS FAHRZEUGEN

In der letzten Zeit nimmt die Anzahl der Eigentumsstraftaten weltweit zu, einschließlich des Diebstahls Außenautoteile.

Mit dem heftigen Anstieg vom Preis für Edelmetalle wie Platin, Palladium und Rhodium hat die Anzahl der Diebstähle von Fahrzeugkatalysatoren in Autos such crimes in the absence of intelligence and forensic information is extremely low.

Conclusions. The afore-mentioned indicates that there is a sharp increase in the number of thefts of catalytic converters installed in cars of certain brands in many countries.

In view of the above, possible legislative and investigative-forensic measures should be suggested to combat this type of crime:

- law enforcement agencies investigating these crimes should remember that it is not about certain unrelated cases but about clearly planned actions of criminal groups;

- it is crucial to strengthen control over metal buying and selling, which are carried out without accounting and corresponding documentation, as well as to amend the Administrative Procedure Code. Such actions should complicate the process of stolen parts supply for criminals;

- application of special forensic marking on parts, including on the catalytic converter, will enable to track its location and provide full information to law enforcement agencies as to the vehicle from which it was stolen. Such an approach will significantly facilitate work for pre-trial investigation bodies in gathering evidence on thefts of parts not having identification marks and features;

- inspection and investigation by an expert-criminalist of vehicles and other physical evidence left by criminals at a crime scene like presence of fingerprints and DNA profiles of criminals will help to considerably increase the disclosure of such type of crime.

Summarizing the above, it should be stressed that with decrease in the number of noble metals extraction and increase in their demand on the market, there is a significant increase in their value. The number of thefts of catalytic converters and other parts will not only not decrease, but this type of crime will begin to increase and spread, including those countries where a substantial increase in the number of thefts of catalysts has not yet been detected.

The structure of rule of law and legislative bodies must be prepared to such a scenario and to take measures in advance for its prevention, also focusing on practical experience from other countries having faced this problem.

\section{References}

Pandemic Brings Spike In Theft Of Cars And Catalytic Converters, Forbes Advisor 2021. URL: https://www.forbes.com/advisor/car-insurance/stolen-cars-catalyticconverters [in English].

Sallybanks, J., \& Thomas, N. (2000). Thefts of External Vehicle Parts: An Emerging Problem. Crime Prevention and Community Safety, 2(3), 17-22. DOI:10.1057/ palgrave.cpcs.8140062 [in English].

Milton, B. E. (1998). Control Technologies in Spark-Ignition Engines. Handbook of Air Pollution from Internal Combustion Engines, 236-239. DOI:10.1016/b978012639855-7/50047-8 [in English].

Catalytic converter thefts: Surge in cases reported to Met Police, BBC News 2021. URL: https://www.bbc.com/news/uk-england-london-56502390 [in English].

Vzryvnoy rost tsen na rynke palladiya i rodiya (Eng. Explosive growth in palladium and rhodium market prices), 2020. URL: https://gold.ru/news/vzryvnoj-rost-cenna-rynke-palladiya-i-rodiya.html [in Russian].

Europol Supports Dismantling of Gang Specialised in the Theft of catalytic Converters. URL: https://www.europol.europa.eu/newsroom/news/europolsupports-dismantling-of-gang-specialised-in-theft-of-catalytic-converters [in English]. 
Over 1,000 catalytic converters cut from cars in London every month, Evening Standard 2020. URL: https://www.standard.co.uk/news/crime/catalyticconverter-theft-london-a4359216.html [in English].

Catalytic Converter Theft Prevention Advice. URL: https://www.westyorkshire.police. uk/advice/vehicle-crime/vehicle-crime/catalytic-converter-theft-preventionadvice [in English].

Israeli Penal Code 1977, Article No. 413 Theft from or Dismantling of Vehicles (Amendment No. 28) 1990. URL: https://www.nevo.co.il/law_html/ law01/073_002.htm\#Seif327 [in Hebrew].

White gold: how the theft of catalytic converters became a disaster, Mako 2021. URL: https://www.mako.co.il/men-stories/Article-8e69c4614594771027.htm [in Hebrew].

Lorraine Explains: Catalytic converters stolen from under our cars, noses, Driving. URL: https://driving.ca/column/lorraine/lorraine-explains-catalytic-convertersstolen-from-under-our-cars-noses [in English].

Turning The Tide On Catalytic Converter Theft, Police Life. URL: https://www.policelife.co.uk/products/turning-the-tide-on-catalytic-converter-theft [in English].

Received by Editorial Board: 01.04.2021

Suggested Citation:

Pertsev, R. (2021). International Experience in Anti-Theft of Catalytic Converters Installed in Cars. Archives of Criminology and Forensic Sciences. 1(3). 65-71. DOI: https://doi.org/10.32353/acfs.3.2021.06

Funding

This research did not receive any specific grant from funding agencies in the public, commercial, or not-for-profit sectors.

\section{Disclaimer}

The funder had no role in the study design, data collection and analysis, decision to publish, or preparation of the manuscript.

\section{Contributors}

The author contributed solely to the intellectual discussion underlying this paper, case-law exploration, writing and editing, and accept responsibility for the content and interpretation.

\section{Declaration of Competing Interest}

The author declare that they have no conflict of interest.

verschiedener Modelle auch zugenommen. Der Grund für den heftigen Anstieg der Anzahl der Diebstähle dieses speziellen Autoteils war der Gehalt an eine kleine Menge der obigen Edelmetalle in den Teilen.

Das Ziel dieses Artikels ist es, dieses Problem, auf das Rechtspflegeorgane und Legislaturen in vielen Ländern stoßen, zu erörtern und einige Lösungswege vorzuschlagen.

Der Artikel bietet einen Überblick über die Situation bei den Diebstählen von Fahrzeugkatalysatoren in den Ländern der Europäischen Union, den USA und Israel. Die detaillierten Gründe für dieses Problem werden berücksichtigt, Maßnahmen zum Schutz des Fahrzeugs vor Diebstahl werden empfohlen.

Es wurde mögliche legislative und kriminalistische Untersuchungshandlungen zur Verhinderung dieser Art von Straftaten vorgeschlagen:

- Strafverfolgungsbehörden die diese Art vom Verbrechen untersuchen, sollten klar verstehen, dass es nicht um Einzelfälle geht, sondern um das geplante Handeln krimineller Gruppen;

- es ist notwendig, die Kontrolle über Aufkäufe und Verkäufe vom Metall, die ohne Berücksichtigung und entsprechende Unterlagen durchgeführt werden, zu stärken und entsprechende Änderungen der Verwaltungsprozeßordnung in Kraft zu setzen:

- das Auftragen spezieller kriminalistischer Markierungen auf die Teile, u. a. auf den Fahrzeugkatalysator, ermöglicht es im Fall eines Diebstahls, seinen Standort nachzuverfolgen und den Strafverfolgungsbehörden umfassende Informationen $\mathrm{zu}$ geben, aus welchem Fahrzeug er gestohlen wurde;

- die Kontrolle und Untersuchung vom ExpertenKriminalisten der Fahrzeuge und anderer Beweisstücke, die Verbrecher an Tatorten hinterlassen haben, um das das Vorhandensein von Fingerabdrücken und DNAProfilen von Tätern festzustellen, werden dazu beitragen, erheblich den Aufdeckungsgrad dieser Art von der Straftat zu erhöhen.

$\mathrm{S}$ c h $1 \ddot{\mathrm{u} s} \mathrm{~s}$ e $1 \mathrm{w}$ ö $\mathrm{r}$ t e $\mathrm{r}$ : Fahrzeugkatalysator, Palladium, Diebstahl der Autoteile, kriminalistische Markierung 